\title{
Bakk Pál
}

\section{Bálint Gábor Szentkatolna emlékezetében}

Szentkatolna a Bálint Gábor születése 150. évfordulóján emléktáblát állít nagy szülöttje tiszteletére. Szüleinek telke századunk első felében két család tulajdonába került. A szülöi ház helyén Harai Adolf épített új lakóházat - ennek falára került az emléktábla —, míg az udvarrészt Harai János építette be. A család emlékét napjainkig a Bálintok helynév őrzi. 1990 óta pedig a szentkatolnai általános iskola, amely a Bálint Gábor nevét viseli.

Bálint Gábor emléke az eltelt évtizedek során elhalványodott, rokonságán kívül kevesen tartották számon. Azok az intézmények, amelyekkel életében kapcsolatot tartott, illetve az eszperantisták értékelték, ápolták csak emlékét. Születésének 100. évfordulója alkalmából az Erdélyi Múzeum-Egyesület Bölcsészet-, Nyelv- és Történettudományi Szakosztályán György Lajos egyetemi professzor mondott emlékbeszédet', halálának 70. évfordulójára idözítve pedig dr. Bodor András egyetemi professzor méltatta tárgyilagosan. ${ }^{2}$ A Székely Nemzeti Múzeum sem feledkezett meg egykori támogatójáról. A tudós születése 130. évfordulóján a múzeum évkönyvében Zágoni Jenő adott róla rövid, tartalmas ismertetést. ${ }^{3}$

A mai ünnepség egyetemes nemzeti értékeink megbecsülésére is figyelmeztetni kiván. A kis nép - mondotta Veres Péter - a számot, a nagyságot és az eröt becsülettel, a szív és a szellem erejével pótolhatja. Szentkatolna népe ilyen gondolatoktól vezérelve tartotta feladatának Bálint Gábor kiemelését a feledés homályából.

Bálint Gábor sokgyermekes székely földmüves katona-családból származott. Születésének évében, 1844-ben leégett a falu, és a tűzeset 1846-ban megismétlödött. ${ }^{4}$ A természeti csapások súlyát növelte a közteherviselés is, amelyet a császári katonák és lovaik ellátásának anyagi gondja jelentett. 5

Az 1848-as szabadságharc során Háromszék vármegye önvédelmi harcából Szentkatolna lakossága derekasan kivette részét. ${ }^{6}$ Bálint Gábor édesapjā is részt vett a csatákban. A szabadságharc leverése után még súlyosabb terhek nehezedtek a falu lakóira. Az orosz katonák és lovaik ellátása végett a falu népére szigorú beszolgáltatást rớttak ki. ${ }^{7}$

Ilyen körülmények között indult a kis Bálint Gảbor az egykori szülöháztól elöször a mai kántori lak helyén lévő, közel 500 éves múltra tekintő szentkatolnai katolikus felekezeti iskolába, amelyröl önéletírásában ${ }^{8}$ ad hiteles képet. 12 éves, amikor beíratják a kézdivásárhelyi elemi iskolába, aztán Csíksomlyón, Marosvásárhelyen, Székelyudvarhelyen, Nagyvảradon tanul tovább, és ott is érettségizik.

Már 16 éves, amikor megszületik öccse, Benedek, a későbbi híres fametsző mủvész, akinek nevét kiállitásain keresztül megismeri nemesak Kézdivásárhely, Kolozsvár és Budapest, hanem Párizs, London is, s aki végül Békéscsabán telepedik le. Itt hal meg 1920. szeptember 20-án.

Kolozsvári kiállításának megnyitóján dr. Hermann Antal a következőket mondotta: „Félreeső helyen, távol a kultúra és mủvészet eszközeitől és hatásaitól remeteként él. Egy nagy müterme van: a természet, nagy modellje: a nép." ${ }^{\text {"9 }}$ A kivảló tehetségü képzőmủvész emléke különben éppoly méltatlanul süllyedt a feledés homályába, mint testvérbátyjáé, a híres tudósé.

J György Lajos: Bálint Gábor emlékezete. Erdélyi Tudományos Intézet Évkönyve 1944. Kolozsvár 1945.

2 Bodor András: Az orientaliszrika ès a hazai magyar keletkutatás II. Korunk, 1983.9.

3 Zágoni Jenõ: 130 eve születert Szenikasolnai Bálint Gábor. Aluta 1974-75.

${ }_{4}^{4}$ Falujegyzökönyv. 1846. március 23.

Falujegyzőkönyv. 1840. április 14.

Történelmi Lapok 1896-97. (Kolozsvár); Dávid Ántal: Háromszék nem alkuszik. Mỏn Kìdỏ, 1973.

7 Falujegyzőkönyv, 1849, augusztus 27.

${ }^{8}$ Szenikatolnai Bálint Gábor önéletrajzi naplótöredéke. Közzéteszì Zígoni Jenỏ. Aluta 1980-81.

9álint Benedek és a székely népmiüv'szet. A Kézdivásáthelyi Székely Társasúg kiadása, 1910. 
A világot járó tudós szükebb pátriájától nem szakadt el. Aggodalommal töltötte el szülöföldjének elmaradottsága és az ebből eredő szegénység. Erről tanủskodik Mikor kezdő́dött a székelység nyomorúsága? címủ írása is. ${ }^{10}$ Mind szóban, mind irásban bírálta az akkori elavult elméleti oktatást, mivel mellözték a gyakorlati ismereteket. Szorgalmazza ipariskolák létesítését. A nép felemelkedésének lehetőségét már akkor a villamositásban és az iparosításban látta. Segítő szándékának szellemi kisugárzása a múlt század végén serkentőleg hatott Szentkatolna életére, amelyet az akkor történt változások igazolnak. Ekkor hozza létre Bardocz Mihály tanító a Kisgazdakört és az Olvasókört. A fiatal Hamar Endre tanító nemesített csigolyaültetvényt telepit, kosárfonó tanfolyamot indít, és gyümölcsfa-iskolát létesít. A selyemhernyó-tenyésztés bevezetése céljából a templom előtti pázsitot eperfákkal ülteti be, viszont az éghajlati viszonyok miatt ez nem vált be. Ennek emlékét még ma is néhány öreg eperfa örzi.

Századunk közepén még beszéltem olyan idős emberekkel, akik látták vagy éppen személyesen ismerték az idős professzort. Emlékezetükben föleg olyan epizódok maradtak meg, amelyek szokatlanságuk miatt vonták magukra a falusiak figyelmẹt. A 90 éves Pál Mári néni Bálint Gảbor alakjára így emlékezett vissza: „Egyenes tartásủ, középmagas, gyors mozgású, kemény ember volt. Dús szakálla, dús fekete haja, széles homloka és éles villogó szemei voltak. Mint fiatal leány, néha azt hittem, hogy valamiért haragszik, de ha megszólalt, nagyon kedvesen, barátságosan beszélt" - mondotta Mári nẻni.

Szülei halála után Szentkatolnán rokonainál, legtöbb időre húga családjánál, Rozáliánál szállt meg, aki Serény László kovácsmester felesége volt. Gyakran látogatott el rokonához, Bakk Ádámnéhoz, de felkereste Katalin testvérét is. A falu ifjúsága az akkor fiatal Hamar Endre tanitó vezetésével nemegyszer találkozott vele Serény László lakásán, ahol csodálkozva hallgatták a nagy utazó-tudós érdekes, népszerủ elöadásait; mindig szivesen fogadta az érdeklődő látogatókat.

Gyakran kereste fèl a szülőháza szomszédságában élő idősebb barátját, a visszavonultan élö Demény Gábort, akinél meghitt beszélgetéssel töltötte idejét.

„Mintha most is magam elött látnám - mondta nekem a 95 éves Kocsis István bácsi az útfelöli házban szoktak beszélgetni. Ott ült az ablak mellett az a nagy tudós ember. $\mathrm{Az}$ asztalon előtte vízipipa volt. Esténként mint kisinas én vittem haza kocsival Serény László házához. Katonásan lépett le a kocsiról, és mosolyogva nyomott 20 krajcárt a kezembe."

Gondjaiba merülve a tudós néha kisétált a Feketeügy partjára, amint azt valamikor gyermekkorában tette. Elnézte az ott sétáló gólyákat. Talán tehetett is valamilyen megjegyzést szóban vagy csak gondolatban, mert a mezỏn közelẻben dolgozỏ egyszerü emberek ezt látva, azt híresztelték, hogy Indiában még a gólyák nyelvét is megtanulta.

A hogy ö érezte, hogy a nép gyermeke, a nép is testvérének, gyermekének tartotta. A falu lakói először nála láttak gramofont, amit ő ismertett meg velük. Az idős emberek még századunk közepén is beszéltek arról a régi „,beszélö gépről”. Az első gramofonhallgatás élményéböl még dr. Györbíró László nagynénje is részesült.

Mint érdekességet beszélte el dr. Bakk Istvản egykor apảmnak a Kézdivásárhely felé kocsikázó Bálint házaspár nyújtotta látványt: „A sárga homokfutó kocsi hátsó ülésén feszes testtartással ült egymás mellett a Bálint hảzaspár. Vállukról világos színủ bő gallér omlott térdükre. Fejükön drapp színü trópusi sisak magasodott. Egyik kezük az oldaluk mellett lévö esernyö fogóján pihent." (Ez az esernyő jó állapotban Dobolyi Zoltánné Bakk Amália örököseinél van, melyet fényképeivel és gyászjelentésével együtt óriznek.) Ezt a látványt a falu népe hamar megszokta, csupán a kézdivásárhelyi járókelőknek tủnt fel. Függetlenül attól, hogy öltözködési kultúrája eltért az átlagtól, ő maga szerény, barátságos ember volt. Gyülölte a hazug embert, és kerülte a képmutató ember társaságát is.

Számtalanszor juttatta kifejezésre szentkatolnai látogatói előtt is, hogy a népek csak akkor fogják igazán tisztelni egymást, ha kölcsönösen ismerik egymás életét és kicserélhetik gondo-

${ }^{10}$ Székely Nemzet 1901. 193. sz. 
lataikat. $\mathrm{Az}$ anyanyelv mellett egyedüli idegen nyelvnek az eszperantót ajánlotta, hogy mint nemzetközi nyelv a népek közti kapcsolatteremtésben kiküszöbölné a sok idegen nyelv elsajátításával járó fáradságot. A kolozsvári tudományegyetem lelkes hallgatóinak kérésére eszperantó nyelvtant sokszorositott, és eszperantó tanfolyamot indított.

A korabeli diáklapban olvassuk: „... az egyetemi ifjúság körében igen sokan elhatározták, hogy az eszperantó nyelvet elsajátítják..."

A harmincas években Baka Laszló tanitó egy évzáróra azt a Bálint Gábor által tamilból forditott verset szavaltatta, amelyet a tudós a kolozsvári egyetemen 1894. február 19-i székfoglalóján a pályaválasztó hallgatóknak ajánlott:

\author{
„Határtalan a tudomány \\ $S$ a tanulók napja csak néhány. \\ Sok a baj, ha elgondolod, \\ Tanuld hát a neked valót. \\ Követve az okos hattyút, \\ Mely tejes vizből tejet ivott."
}

Az anyagiakban igénytelen tudós volt, pedig ha hatalmas tudását más irányban kamatoztatta volna, mérhetetlen vagyonra tehetett volna szert, de öt nem a pénz, hanem nemzetének múltja érdekelte. Idős korában három dologra volt büszke: szentkatolnai előnevére, amellyel a faluhoz való kötődésén kívül székely magyarságát fejezte ki; tiszteletbeli doktori címére, amellyel a kolozsvári tudományegyetem az iránta való elismerését juttatta kifejezésre, végül azokra a tudományos munkáira, amelyeket előtte senki sem végzett el.

A tudós szentkatolnai látogatásai egyre gyérültek, míg végre elmaradtak. Egy évvel nyugalomba vonulása után, Temesváron a Piffl házban, a régi Hunyadi út 14. szám alatt hunyt el 1913. május 26-án, 69 éves korában.

A nagy utazónak halála után is vándorolnia kelletu. Tévedésból koporsóját a vonat Kézdivásárhely helyett Marosvásárhelyre vitte. Holtteste csak ezzel a kerülővel jutott Kézdivásárhelyre, ahol a református temetőben helyezték örök nyugalomra. ${ }^{12}$

Bảr a tudományt szolgáló élete sokban hasonlított a Körösi Csoma Sándoréhoz, emléke csaknem feledésbe merült. A lexikonok hiảnyosan vagy egyáltalán nem emlékeztek meg róla, igy az 1981-ben kiadott Romániai Magyar Irodalmi Lexikon sem, holott „emlékezete” — e kötetben is találunk rá bizonyitékokat - halála után is élt szükebb pátriájában.

Ahogy élete során Bálint Gábort Erdélyben és szülöföldjẻn, Háromszéken, Szentkatolnán földijeinek, barátainak szeretete övezte, úgy ma is, több évtizeddel halála után ugyanolyan szeretettel kell örizzük emlékét. Emlékezni nemcsak jogunk, de kötelességünk is. Más kultúrákat is csak akkor tudunk igazán értékelni, ha elöbb megismertük a magunkét, azt ápoljuk és életben is tartjuk. Különben - amint Bálint Gábor maga mondta: „Az, aki tudományával, még ha nyelvészet is az, valamely nemzetnek nem emelésére, hanem önbizalmának csökkentésẻre törekszik, nem kenyeret érdemel azon nemzet részéről, hanem egyebet." ${ }^{\text {13 }}$

Így emlékezünk Bálint Gáborra, hogy emlékeztessünk!

\footnotetext{
${ }^{11}$ Kolozsvári Egyetemi Lapok 1897. okt. 2.

12 Bálinı Gábor életútjáról és munkásságáról, illetve a słälőtalu emlékezetében élö alakjáról lásd Bakk Pál: $F e l$ jegyzések Bálin Gáborról. Korunk 1969. 12.

Székely Nenzet 1896 . I. sz.
} 


\section{Bálint Gábor, Pröhle Vilmos és a japán-magyar nyelvhasonlítás története}

1. 150 év telt el azóta, hogy 1844. március 13-án megszületett Bálint Gábor (1844-1913) a Háromszék megyei Szentkatolnán (Catalina, ma Románia), az akkori Magyarország keleti szélén. A székely tudós, miután több mint egy évtizedig hányódott Európában és Ázsiában, visszatért hazájába, és a kolozsvári Királyi Ferenc József Tudományegyetemen az urál-altaji összehasonlitó nyelvészet tanáraként oktatott az 1893/94. tanév 2. felétöl az 1911/12. tanévig. 1977-ben Ligeti Lajos a Gombocz Zoltán mint turkológus címü cikkében a következőket írta: „Bálintot az altaji nyelvek érdekelték csupán, használható, jó anyagot közölt törökböl (kazáni tatárból) és mongolból (burjátból). Összehasonlító nyelvészetből csak meghökkentően dilettáns müveket produkált (magyar-mongol, magyar-dravida, magyar-kabard nyelvrokonság). Az ő helyére került 1914-ben Gombocz Zoltán, megjelenése a katedrán alig mérhető színvonal-emelkedést jelentett."' György Lajos irodalomtörténész pedig, aki 50 évvel ezelött elöadást tartott Bálint életéröl és munkásságáról születésének 100. évfordulója alkalmából, arról szólt, hogy „A méltánytalanság ott érte Bálint Gábort, amikor tévedései mögött nem látták és nem is becsülték meg azt a pozitiv értékanyagot, amelyet Oroszországban és Azsiában, nagy tudással és kifogástalan módszerrel, a tudomány számára hozzáférhetövé tett."² Munkái egyes részeinek értékét mutatja, hogy az utóbbi évtizedekben török, mongol és mandzsu vonatkozású müveit utánnyomásból vagy kéziratából megjelentetik. ${ }^{3}$

Az alábbiakban elöször Bálintnak egy terjedelmes dolgozatáról szeretnék szólni, amely a japán-magyár nýelvhasonlitás történetének szempontjából érdekes, és tudtommal az ismeretlenség homályában hever. Ismeretes, hogy a székely nyelvész tagja lett Széchenyi Béla keletázsiai expedíciójának, amely 1877 decemberében indult Triesztből, de egyedül ö indult vissza hamarabb Európába, 1878 tavaszán. György Lajos azt állitja, hogy Bálint Sanghajból „Japánba is átnézett". Maga Bálint azonban a "Minó fajuiak a japánok (nipponiak)? címü, "1894-ben megjelent cikkében' nem szól japáni tartózkodásáról, amikor a japánokkal való első (1872-ben Szentpétervárott) és második (1878-ban Sanghajban) találkozásảról beszẻl, és 1878-ban még a „legkisebb gondot sem” forditotta a japán nyelvre. Később pedig ez a nyelv nagyon foglalkoztathatta öt, és a fent említett 1894-es cikkében azt írja, hogy „Több mint 800 (nyolcszáz) magyar alapszónak társait tudom kimutatni a nipponi nyelvben". Ezen szóegyeztetései néhány év múlva valóban napvilágot láttak, de - úgy tünik - nem szerzett tudomást róluk a magyar tudomány világa.

Ezzel kapcsolatban említést érdemel az, hogy tudósunk a kolozsvári egyetemen, ahol föleg altaji nyelvekröl adott elö, az egyetemi tanrend szerint az 1895/96. tanévtöl nyolc féléven keresztül tanitott japán nyelvet is heti két órában. ${ }^{6} \mathrm{Az} 1895 / 96$. tanév 1 . fẻlévére vonatkozó tanrend a következö óráit hirdeti: Kabard nyelvtan. Heti egy óra. | Nipponi nyelvtan. Heti 2 óra. | Török-tatár nyelvtan és szövegolvasás. Heti 2 óra. | Ta hio (A nagy tan) mandzsu nyel-

${ }^{1}$ MNy. LXXIII. 396.

${ }^{2}$ György Lajos: Bálint Gábor cmlekczete. Egy kolozsvári egyetemì tanảr oroszorszảgì és belsỏảzsià nyelvtanulmányai. Kolozsvár 1945. 29; 1. még Zágoni Jenö: 130 éve született Szentkatolnai Bálint Gábor. Aluta VI/VII (1974/75), 373-89.

${ }_{3}^{3}$ L.: Louis J. Nagy: Acta Orientalia IX (1959), 311-27; G. Kam: Narody Azii i Afriki 1962/1, 161-4; Bálint Gábor keleti levelei. Bevezetövel újm közreadja Kara György. Bp., 1973.; Wolgatatarische Dialektstudien. Textkritische Neuausgabe der Originalsammlung von G. Bálint 1875-1876. Hrsg. von A. Berta. Bp., 1988.

I. $m .17$

${ }^{5}$ Erdélyi Múzeun XI, 584-5.

'György (i. m. 22.) csak négy félévröl beszél. 